\title{
REARING THE LARVAE OF THE BLOWFLY CHRYSOMYA CHLOROPYGA (WIEDEMANN) (DIPTERA, CALLIPHORIDAE) ON OLIGIDIC DIETS
}

TÂNIA T. DE SOUZA LEAL ${ }^{1}$ ÂNGELO PIRES DO PRADO² ABSTRACT ALOISIO JOSE ANTUNES ${ }^{1}$

The growth of Chrysomya chloropyga (Wiedemann) larvae was compared on three different oligidic diets and mice carcass. The following performances in terms of gain in body weight were obtained: mice carcass $(61.5 \mathrm{mg})$, whole dried milk plus whole dried egg $(56.5 \mathrm{mg})$, whole dried milk plus casein $(56 \mathrm{mg})$ and whole dried milk $(53 \mathrm{mg})$. The period of most rapid growth was also different for each dietary media. This is the first time C. chloropyga has been reared on oligidic diets.

\section{INTRODUCTION}

Calliphoridae flies have been successfully reared on synthetic media for different research purposes. However, the larva of the blowfly Chrysomya chloropyga (Wiedemann) has been only grown on animal carcass, flesh and liver (Ullyett, 1950; Smit, 1931; Cuthbertson, 1933).

C. chloropyga, an African blowfly recently introduced in Southern Brazil (Imbiriba et al., 1978; Guimarães et al., 1978, 1980) is easily reared in laboratory conditions, being an animal particularly useful for biological experiments.

Stoffolano (1974) developed an oligidic diet in which the ingredients were whole dried milk, dried brewer's yeast and water. His results have demonstrated satisfactory development of the gonads and accessory reproductive glands of the black blowfly Phormia regina (Meigen).

Singh (1976) improved Stoffolano's diet by adding commercial casein to it. He was able to demonstrate the beneficial effect of such addition on the growth of Mystacinobia zelandica Holloway (Mystacinobiinae) larvae.

The objective of this study was to compare the growth of $C$. chloropyga larvae when fed on four different diets; whole dried milk, whole dried milk-plus-casein, whole dried milk-plus-whole dried egg, and on the natural mice carcass.

Stock cultures

\section{MATERIAL AND METHODS}

Colonies of adult $C$. chloropyga were kept in large nylon-screen trapezoidal cages $(34 \times 20 \times 2 \times 26 \times 50 \mathrm{~cm})$ in a temperature controlled room at $25^{\circ} \mathrm{C} \pm 1^{\circ} \mathrm{C}, 80 \%$ relative humidity and submitted to a 12 hours photoperiod. The flies were fed on a dry mixture (whole dried milk, dried brewer's yeast and sucrose) and water given separately. Both were supplied ad libitum.

\section{Egg collection}

The substrates used for egg deposition were mice carcass or sliced beef liver. The eggs were washed with distilled water and then rinsed with $1 \%$ $\mathrm{NaHSO}_{2}$ solution for dissolving the cement. 200 to 300 washed eggs were

1. Faculdade de Engenharia de Alimentos, Universidade Estadual de Campinas.

2. Departamento de Parasitologia, Instituto de Biologia, Universidade Estadual de Campinas. 
transferred to each glass bottle (containing approximately 50 grams of medium or mice carcass). The amount of available diet was not a limiting factor. The bottles were incubated at $30^{\circ} \mathrm{C} \pm 1^{\circ} \mathrm{C}$ for a period of 125 hours.

Measurement of larval growth

For every 8 hours during a period of time of 125 hours, groups of 10 larvae were cleaned by immersion in distilled water, dried on filter paper and weighed. Their average weight in milligrams were recorded. The larvae grown on mice carcass had their weight recorded at different time intervals.

The larvae were discarded after weighing.

Diets

The composition of the diets is shown in Tables 1,2 and 3. The nitrogen content of the diets was determined as described by the Association of Official Analytical Chemists (1980). Crude protein was obtained by multiplying the nitrogen content by 6.25 . Table 4 shows the crude protein content of the diets.

The different diets were homogeneized in an waring-blender and dispensed in 50 grams portions to glass bottles.

Table 1 - Composition of the whole dried milk diet.

$\begin{array}{lr}\text { Ingredients } & \text { Weight (g) } \\ \text { Whole dried milk } & 10.0 \\ \text { Dried brewer's yeast } & 10.0 \\ \text { Agar (1) } & 2.0 \\ \text { Nipagin (2) } & 0.4 \\ \text { Water } & 100.0 \\ \text { (1) Difco Laboratories } & \\ \text { (2) Methyl-p-hydroxybenzoate } & \end{array}$

Table 2 - Composition of the whole dried milk-plus-casein diet.

Ingredients
Whole dried milk
Dried brewer's yeast
Casein (1)
Agar (2)
Nipagin (3)
Water
(1) Commercial casein
(2) Difco Laboratories
(2) Methyl-p-hydroxybenzoate

Weight (g)

10.0

10.0

0.5

2.0

0.4

100.0

Table 3 - Composition of the whole dried milk-plus-whole dried egg diet.

Ingredients

Whole dried milk

Whole dried egg

Agar (1)

Nipagin (2)

Water

(1) Difco Laboratories

(2) Methyl-p-hydroxybenzoate
Weight $(\mathrm{g})$

10.0

10.0

2.0

0.4

100.0

Table 4 - Protein content of the diets $(\mathrm{N} \times 6.25)$

Diets

Whole dried milk

Whole dried milk-plus-casein

Whole dried milk-plus-whole
Protein (\%)

4.9

5.3

5.8 


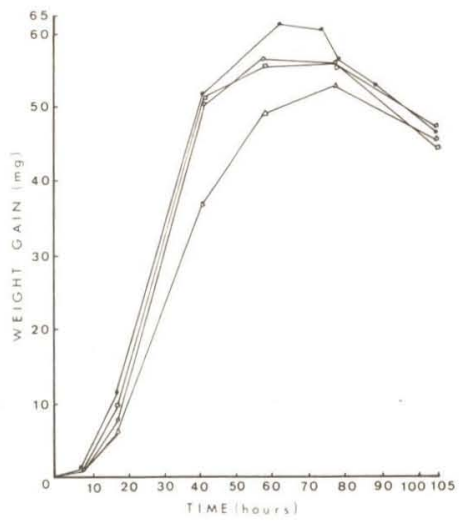

Fig. 1 - Growth of the larvae of Chrysomya chloropyga on mice carcass (dot), whole dried milk plus whole dried egg (circle), whole dried milk plus casein (rectangle) and whole dried milk (triangle) diets.

\section{RESULTS AND DISCUSSION}

Diptera larvae are among the most rapidly growing metazoans. The larva of Chrysomya chloropyga, starting from a weight of less than $0.5 \mathrm{mg}$, reaches a final weight (maximum weight) of $61.5 \mathrm{mg}$ within a span of 63 hours. This fast rate of growth permits one to carry out large number of biochemical or nutritional studies over a relatively short period of time.

The effect of whole dried milk, whole dried milk-plus-casein, whole dried milk-plus-whole dried egg on the growth of C. chloropyga larvae is illustrated in Figure 1 where it is possible to compare it with the growth of the larvae on mice carcass.

For the larvae grown on mice carcass the maximum weight is obtained within 63 hours when they have reached $61.5 \mathrm{mg}$. For the dried whole milk-plus-whole dried egg diet the maximum weight $(56.5 \mathrm{mg})$ was attained after 58 hours; a maximum weight of $56 \mathrm{mg}$ was reached by the larvae grown on dried whole milk-plus-casein diet after 78 hours, for the dried whole milk diet maximum weight of $53 \mathrm{mg}$ was obtained after 78 hours.

The results for growth rates can be explained by differences in protein quality of the diets, being the whole dried milk diet improved when casein and whole dried egg are added to it. As we have seen growth is not quite so rapid in the experimental diets, as well as, the gain in body weight, as compared to that in the natural mice carcass.

The absence of dried brewer's yeast from the whole dried milk-plus-whole dried egg diet was not detrimental to the growth of the larvae. In fact, the best results were shown by the larvae fed on this diet, compared to the other two experimental diets. The importance of dried brewer's yeast as a component of diets for this type of larvae is due to its content in vitamin B complex and nucleic acids which are required for optimum growth. This essentiality was pointed out by Brust and Fraenkel (1955) when studying the nutritional requirements of Phormia regina (Meigen). Whole dried egg was a good substitute for the dried brewer's yeast since it is a good souree of 
both vitamin B complex and nucleic acids. Moreover, its proteins have a

high biological value, being able to supplement the proteins which are present in the whole dried milk.

\section{REFERENCES}

Association of Official Analytical Chemists, 1980. Official methods of analysis. 13. Ed.

Brust, M. \& G. Fraenkel, 1955. The nutritional requirements of the larvae of a blowfly, Phormia regina (Meig.). Phys. Biol. 28: 186-204.

Cuthbertson, A., 1933. The habits and life histories of some Diptera in southern Rhodesia. Proc. Rhod. Sci. Ass. 32: 81-111.

Guimarães, J. H., A. P. do Prado \& A. X. Linhares, 1978. Three newly introduced blowfly species in southern Brazil (Diptera, Calliphoridae). Revta bras. Ent. 22(1): 53-60.

Guimarães, J. H., A. P. do Prado \& G. M. Buralli, 1980. Dispersal and distribution of three newly introduced species of Chrysomya Robineau-Desvoidy in Brazil (Diptera, Calliphoridae). Ibid. 23(4): 245-255.

Imbiriba, A. S., D. T. Izutami, I. T. Milhoretto \& E. Luz, 1978. Introdução de Chrysomya chloropyga (Wiedemann, 1818) na região neotropical (Diptera, Calliphoridae). Arqos Biol. Tec. 20: 35-39.

Singh, P., 1977. Artificial foods for the batfly Mystacinobia zelandica Holloway (Diptera, Calliphoridae). N. Z. J. Zool. 4(3): 331.

Smit, B., 1931. A study of the sheep blowflies of South Africa. Onderstepoort J. Vet. anim. Ind. 17: 299-421.

Stoffolano, J. G., Jr., 1974. Influence of diapause and diet on the development of the gonads and accessory reproductive glands of the black blowfly Phormia regina (Meig.). Can. J. Zool. 52: 981.

Ullyett, G. C., 1950. Competition for food and allied phenomena in sheep blowfly populations. Phil. Trans. r. Soc. Lond. 234: 77-174. 